\title{
A 3D Porous Metal-Organic Framework Exhibiting Selective Adsorption of Water over Organic Solvents
}

Jin-Zhong Gu, Long Jiang, Wen-Guan Lu, Hong-Cai Zhou, and Tong-Bu Lu*

Table S1. Selected bond lengths $(\AA)$ and angles $\left({ }^{\circ}\right)$ for $\mathbf{1}^{a}$

\begin{tabular}{|c|c|c|c|c|c|}
\hline $\mathrm{Zn}(1)-\mathrm{O}(1)$ & $1.967(5)$ & $\mathrm{Zn}(1)-\mathrm{O}(3)$ & $2.064(5)$ & $\mathrm{Zn}(1)-\mathrm{O}(5)$ & $2.179(4)$ \\
\hline $\mathrm{Zn}(1)^{-\mathrm{N}}(3)$ & $1.988(5)$ & $\mathrm{Zn}(1)-\mathrm{N}(5)$ & $2.046(6)$ & $\mathrm{Zn}(2)-\mathrm{O}(4 \mathrm{ii})$ & $2.248(5)$ \\
\hline $\mathrm{Zn}(2)-\mathrm{O}(6)$ & $2.046(5)$ & $\mathrm{Zn}(2)-\mathrm{O}(7)$ & $1.991(4)$ & $\mathrm{Zn}(2)^{-} \mathrm{O}(9 \mathrm{iii})$ & $1.936(5)$ \\
\hline $\mathrm{Zn}(2)-\mathrm{N}(2 \mathrm{ii})$ & $1.998(5)$ & $\mathrm{Zn}(3)-\mathrm{O}(2 \mathrm{i})$ & $2.228(5)$ & $\mathrm{Zn}(3)-\mathrm{O}(8)$ & $2.252(4)$ \\
\hline $\mathrm{Zn}(3)^{-} \mathrm{O}(9)$ & $1.935(5)$ & $\mathrm{Zn}(3)-\mathrm{N}(1 \mathrm{i})$ & $1.967(5)$ & $\mathrm{Zn}(3)-\mathrm{N}(4)$ & $1.960(5)$ \\
\hline $\mathrm{O}(1)-\mathrm{Zn}(1)-\mathrm{N}(3)$ & $129.3(2)$ & $\mathrm{O}(1)-\mathrm{Zn}(1)-\mathrm{N}(5)$ & $112.5(2)$ & $\mathrm{N}(3)-\mathrm{Zn}(1)-\mathrm{N}(5)$ & $115.6(2)$ \\
\hline $\mathrm{O}(1)-\mathrm{Zn}(1)-\mathrm{O}(3)$ & $99.57(19)$ & $\mathrm{N}(3)-\mathrm{Zn}(1)-\mathrm{O}(3)$ & $89.2(2)$ & $\mathrm{N}(5)-\mathrm{Zn}(1)-\mathrm{O}(3)$ & $97.7(2)$ \\
\hline $\mathrm{O}(1)-\mathrm{Zn}(1)-\mathrm{O}(5)$ & $86.33(18)$ & $\mathrm{N}(3)-\mathrm{Zn}(1)-\mathrm{O}(5)$ & $77.0(2)$ & $\mathrm{N}(5)-\mathrm{Zn}(1)-\mathrm{O}(5)$ & $92.0(2)$ \\
\hline $\mathrm{O}(3)-\mathrm{Zn}(1)-\mathrm{O}(5)$ & $165.62(19)$ & $\mathrm{O}(9 \mathrm{iii})-\mathrm{Zn}(2)-\mathrm{O}(7)$ & $106.0(2)$ & $\mathrm{O}(9 \mathrm{iii})-\mathrm{Zn}(2)-\mathrm{N}(2 \mathrm{ii})$ & $122.6(2)$ \\
\hline $\mathrm{O}(7)-\mathrm{Zn}(2)-\mathrm{N}(2 \mathrm{ii})$ & $128.8(2)$ & $\mathrm{O}(9 \mathrm{iii})-\mathrm{Zn}(2)-\mathrm{O}(6)$ & $102.2(2)$ & $\mathrm{O}(7)-\mathrm{Zn}(2)-\mathrm{O}(6)$ & $97.83(19)$ \\
\hline $\mathrm{N}(2 \mathrm{ii})-\mathrm{Zn}(2)-\mathrm{O}(6)$ & $87.3(2)$ & $\mathrm{O}(9 \mathrm{iii})-\mathrm{Zn}(2)-\mathrm{O}(4 \mathrm{ii})$ & $93.5(2)$ & $\mathrm{O}(7)-\mathrm{Zn}(2)-\mathrm{O}(4 \mathrm{ii})$ & $87.36(18)$ \\
\hline $\mathrm{N}(2 \mathrm{ii})-\mathrm{Zn}(2)-\mathrm{O}(4 \mathrm{ii})$ & $75.57(19)$ & $\mathrm{O}(6)-\mathrm{Zn}(2)-\mathrm{O}(4 \mathrm{ii})$ & $161.29(19)$ & $\mathrm{O}(9)-\mathrm{Zn}(3)-\mathrm{N}(4)$ & $112.9(2)$ \\
\hline $\mathrm{O}(9)-\mathrm{Zn}(3)-\mathrm{N}(1 \mathrm{i})$ & $115.1(2)$ & $\mathrm{N}(4)-\mathrm{Zn}(3)-\mathrm{N}(1 \mathrm{i})$ & $131.9(2)$ & $\mathrm{O}(9)-\mathrm{Zn}(3)-\mathrm{O}(2 \mathrm{i})$ & $101.6(2)$ \\
\hline $\mathrm{N}(4)-\mathrm{Zn}(3)-\mathrm{O}(2 \mathrm{i})$ & $93.6(2)$ & $\mathrm{N}(1 \mathrm{i})-\mathrm{Zn}(3)-\mathrm{O}(2 \mathrm{i})$ & $76.87(19)$ & $\mathrm{O}(9)-\mathrm{Zn}(3)-\mathrm{O}(8)$ & $97.48(19)$ \\
\hline $\mathrm{N}(4)-\mathrm{Zn}(3)-\mathrm{O}(8)$ & $76.54(19)$ & $\mathrm{N}(1 \mathrm{i})-\mathrm{Zn}(3)-\mathrm{O}(8)$ & $97.3(2)$ & $\mathrm{O}(2 \mathrm{i})-\mathrm{Zn}(3)^{-} \mathrm{O}(8)$ & $160.77(19)$ \\
\hline
\end{tabular}




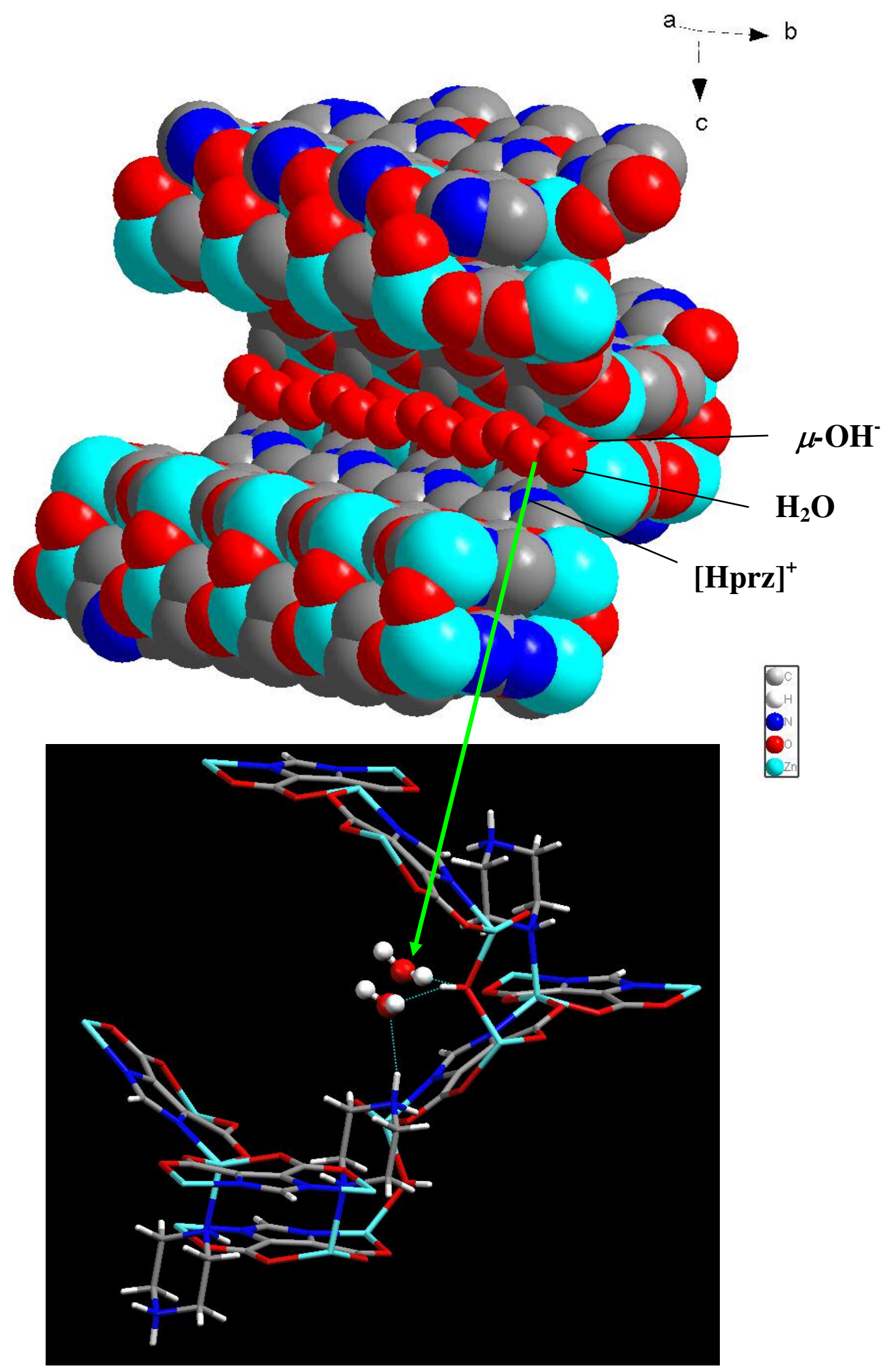

Figure S1. View of the $\mu_{2}-\mathrm{OH}^{-}$and $\mathrm{Hprz}^{+}$on the surface of the channel, and the hydrogen bonded water molecules with the $\mu_{2}-\mathrm{OH}^{-}$and the $\mathrm{NH}$ groups of $\mathrm{Hprz}^{+}$. 


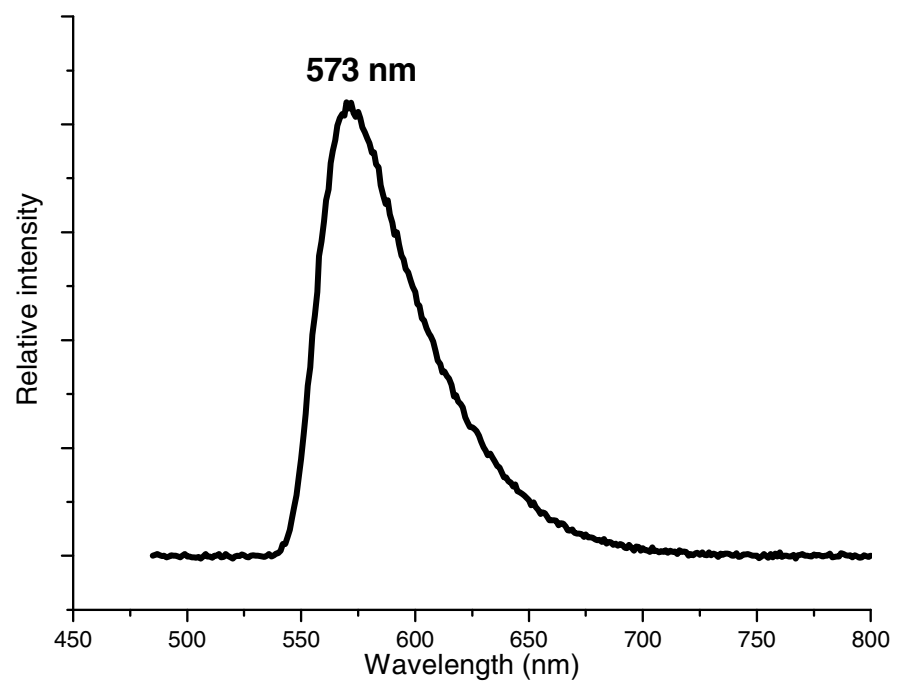

Figure S2. The photoluminescent spectrum of $\mathbf{1}$ in the soild state at room temperature $\left(\lambda_{\mathrm{ex}}=468 \mathrm{~nm}\right)$.

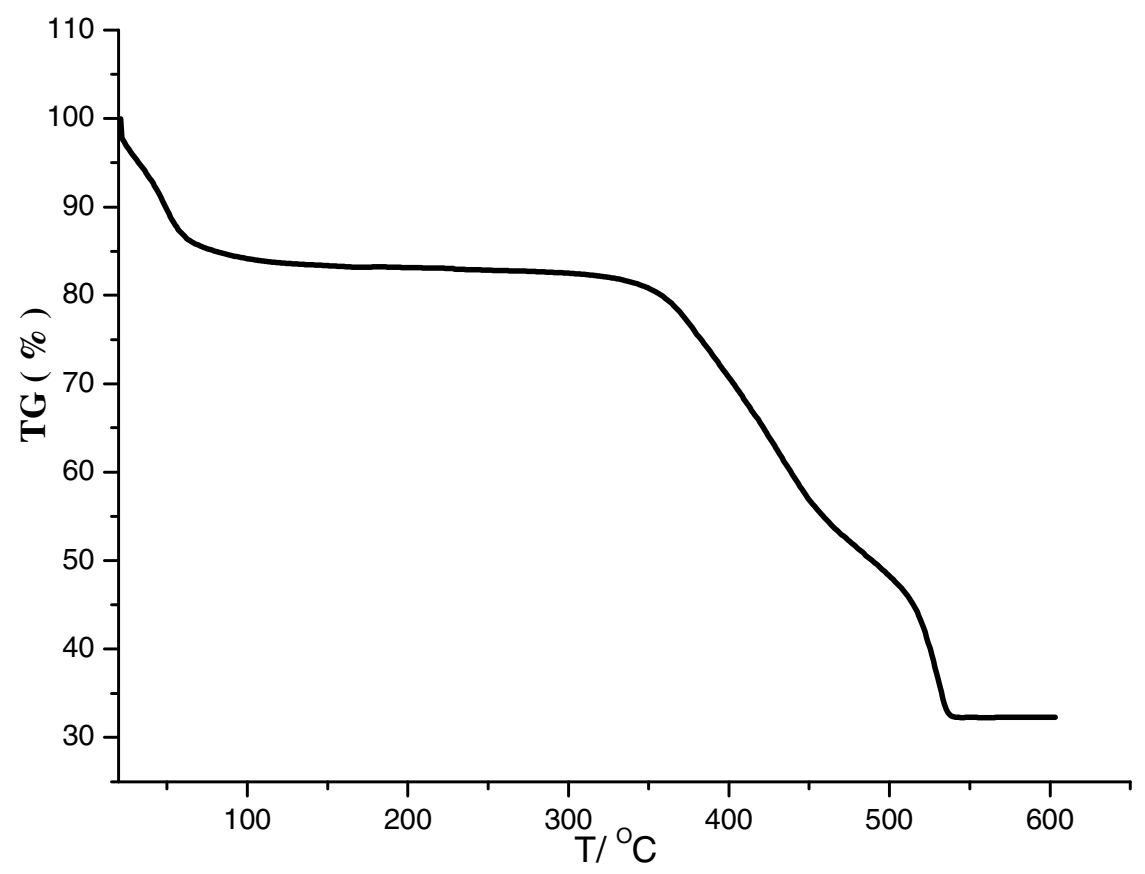

Figure S3. The TGA curve for the crystals of $\mathbf{1}$. 


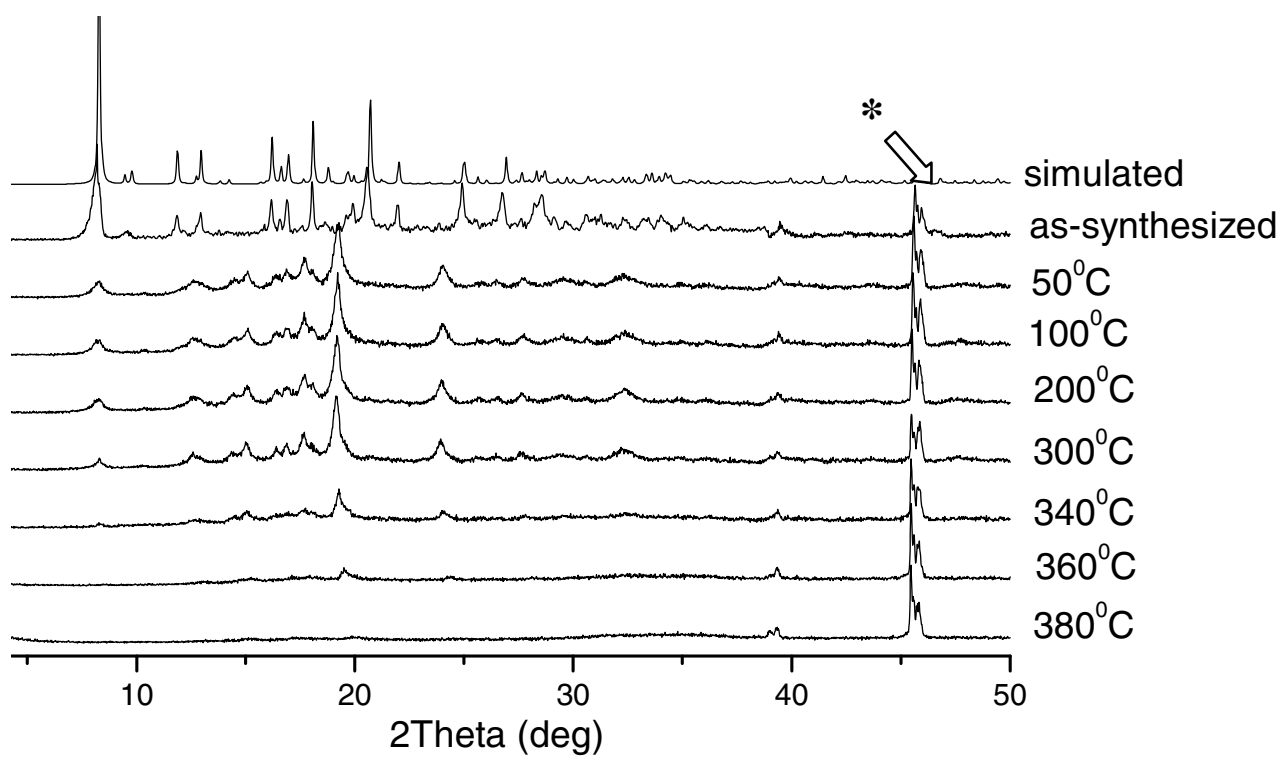

Figure S4. The XRPD patterns of $\mathbf{1}$ at different temperatures, the simulated patterns are generated from single-crystal diffraction data.

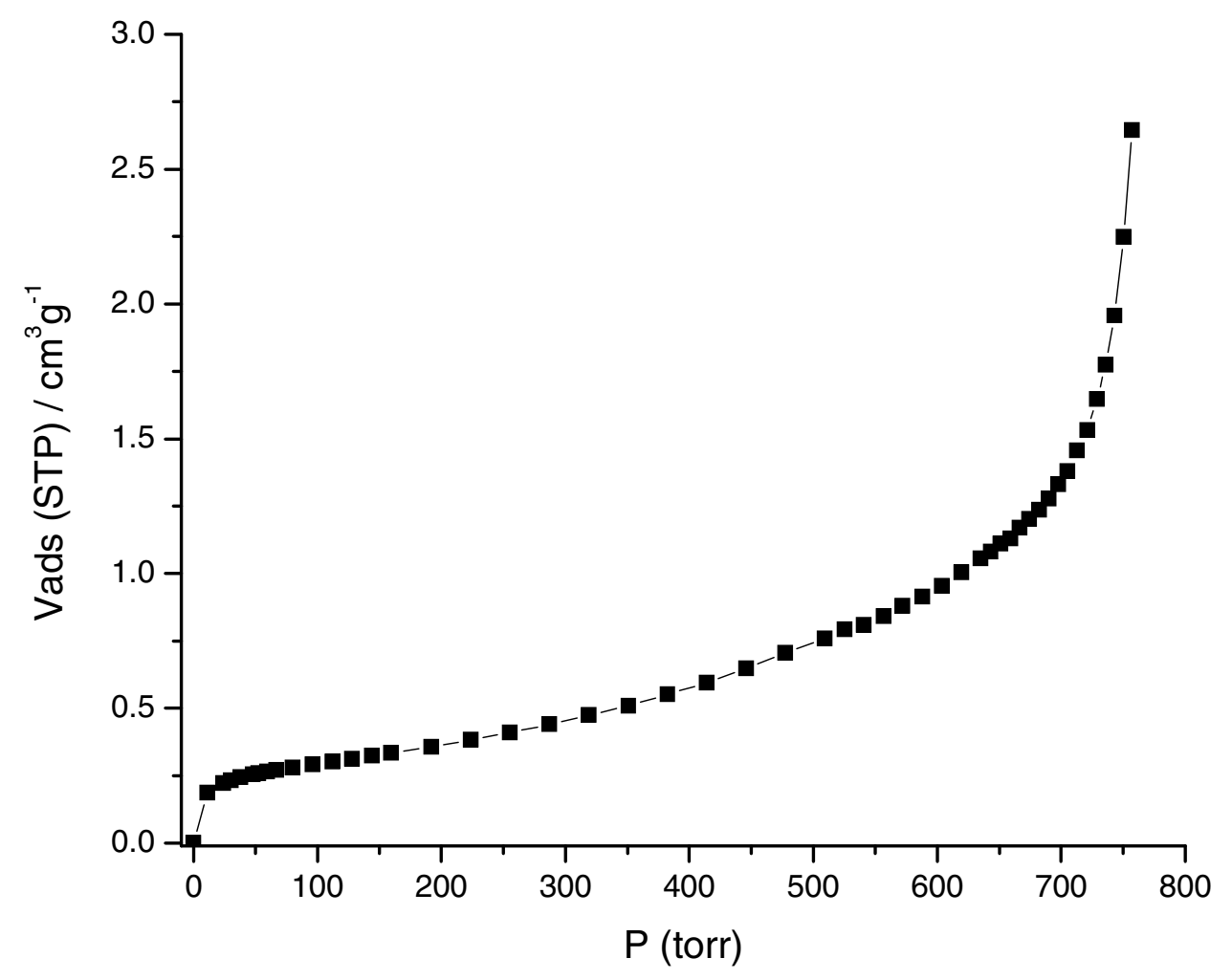

Figure S5. Nitrogen isotherm measurement of the dried crystals, indicating the dried $\mathbf{1}$ becomes non-porous after removing the guest water molecules. 
Adsorption Water from Organic Solvents: The experiments for adsorption water from organic solvents were performed by immersing the dried crystals (under vacuum at $120^{\circ} \mathrm{C}$ for $2 \mathrm{~h}$ ) in different solvents (ethanol, acetone, THF, benzene, toluene and xylene) for $24 \mathrm{~h}$, and then dried in air. It was found that only water molecules were adsorbed from the solvents of methanol, ethanol, acetone, THF and benzene. The existence of toluene and xylene in the isolated samples from toluene and xylene is due to their higher boiling point, in which toluene and xylene were remained at the surface of the sample (it is impossible that toluene and xylene are located in the channels of $\mathbf{1}$, which are occupied by water molecules, and this was confirmed by the results of XRPD (Figure 4) and IR spectra (Figure S7)).

Table S2. Elemental analyses data

\begin{tabular}{l|lccc}
\hline Solvents & \multicolumn{1}{l}{ Compositions } & $\mathrm{C}$ & $\mathrm{H}$ & $\mathrm{N}$ \\
\hline methanol & $\mathbf{1} \cdot 12 \mathrm{H}_{2} \mathrm{O}$ & 23.55 & 3.31 & 11.41 \\
ethanol (95\%) & $\mathbf{1} \cdot 14 \mathrm{H}_{2} \mathrm{O}$ & 23.07 & 3.87 & 11.39 \\
acetone & $\mathbf{1} \cdot 9 \mathrm{H}_{2} \mathrm{O}$ & 24.54 & 3.38 & 12.12 \\
THF & $\mathbf{1} \cdot 13 \mathrm{H}_{2} \mathrm{O}$ & 23.24 & 4.01 & 11.28 \\
benzene & $\mathbf{1} \cdot 8 \mathrm{H}_{2} \mathrm{O}$ & 25.13 & 12.44 & 3.72 \\
toluene & $\mathbf{1} \cdot 12 \mathrm{H}_{2} \mathrm{O} \cdot\left(\mathrm{C}_{7} \mathrm{H}_{8}\right)_{0.8}$ & 26.85 & 11.28 & 3.61 \\
\hline xylene & $\mathbf{1} \cdot 8 \mathrm{H}_{2} \mathrm{O} \cdot\left(\mathrm{C}_{8} \mathrm{H}_{10}\right)_{0.2}$ & 25.75 & 12.23 & 3.41 \\
\hline
\end{tabular}

The TG-MS measurements for the immersing dried crystals in methanol and THF solvents were performed on a Netzsch STA449C QMS-403C instrument under air atmosphere in the 30 300 ${ }^{\circ} \mathrm{C}$ temperature range, with a heating rate of $5^{\circ} \mathrm{C} / \mathrm{min}$. The results indicate the adsorbed guest molecules are water molecules, and no solvent molecules are detected. The TGA curve for the immersed crystals in ethanol (Figure S6) indicates that the weight loss (under $100^{\circ} \mathrm{C}$ ) found of $17.3 \%$ is consistent with the result of elemental analysis $\left(\mathbf{1} \cdot 14 \mathrm{H}_{2} \mathrm{O}, 17.2 \%\right)$. The IR spectra of the immersed crystals in different solvents are identical to that of the original crystals (Figure S7), further indicating that only water molecules are absorbed from different solvents. 


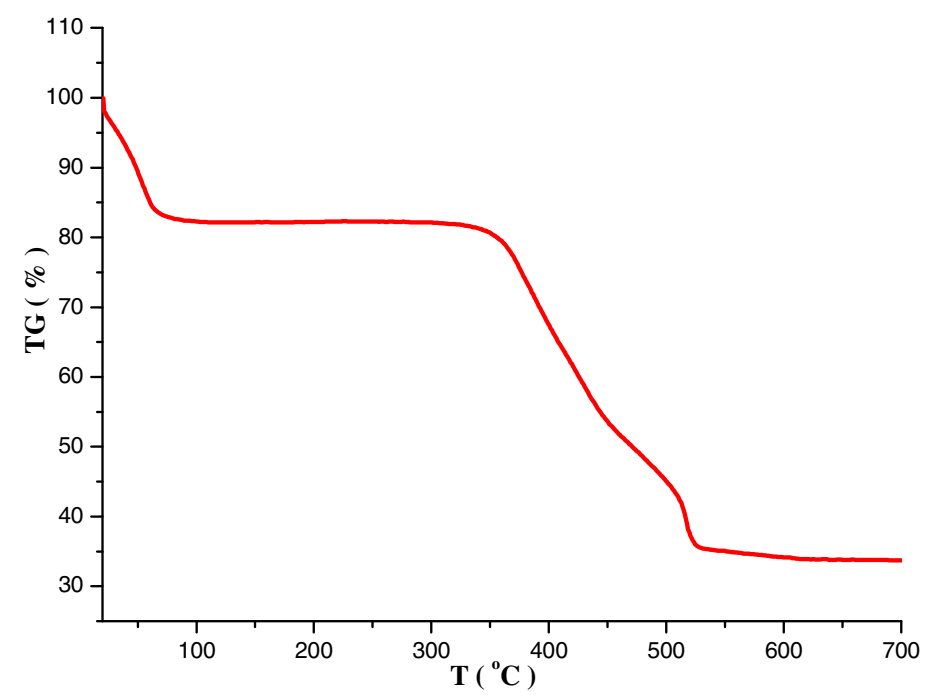

Figure S6. The TGA curve for the immersed crystals in ethanol.

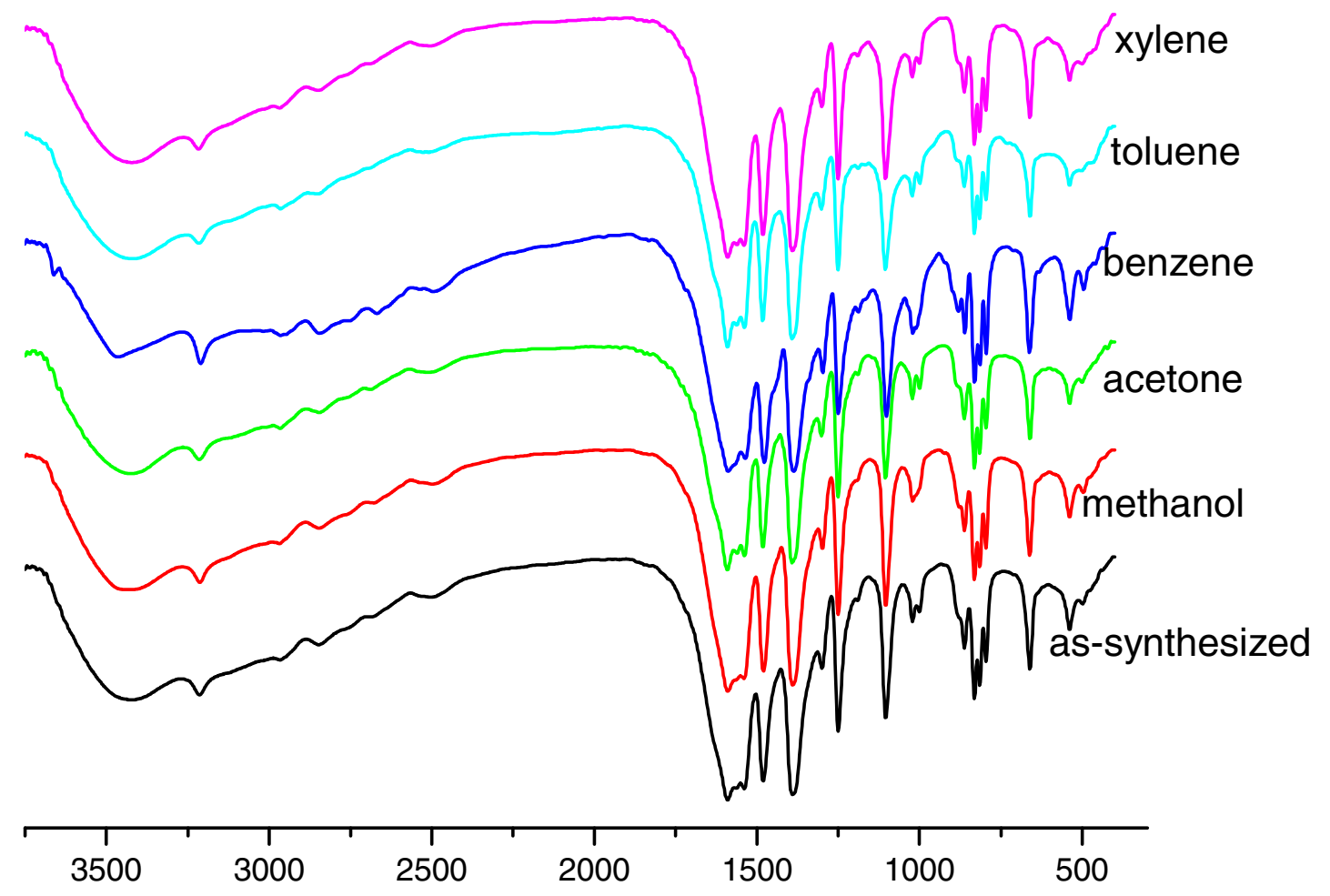

Figure S7. The IR spectra for the synthesized crystals, and the samples after immersing the dried crystals in different solvents for $24 \mathrm{~h}$, indicating only water molecules were adsorbed by the dried $\mathbf{1}$. 
In order to identify the adsorbed water molecules are from organic solvents or atmospheric moisture, the amount of water in methanol, ethanol (95\%) and THF were measured before and after experiments. It was found that the amount of water were reduced after adding the dried crystals of $\mathbf{1}$, indicating the adsorbed water molecules by dried $\mathbf{1}$ are from organic solvents.

Table S3. Experimental results

\begin{tabular}{|c|c|c|c|}
\hline \multirow[t]{2}{*}{ Solvents } & \multirow[t]{2}{*}{ Condition } & \multicolumn{2}{|c|}{ The amount of water in solvents } \\
\hline & & Before adding & After adding of \\
\hline methanol & $\begin{array}{l}20 \mathrm{~mL} \text { of methanol }+ \\
21 \mathrm{mg} \text { dried } \mathbf{1} \text {, leaving } \\
\text { for } 24 \mathrm{~h}\end{array}$ & $0.24 \%$ & $0.18 \%$ \\
\hline ethanol (95\%) & $\begin{array}{l}5 \mathrm{~mL} \text { of ethanol }+30 \\
\mathrm{mg} \text { dried } \mathbf{1} \text {, leaving for } \\
9 \mathrm{~h}\end{array}$ & $7.01 \%$ & $6.80 \%$ \\
\hline THF & $\begin{array}{l}20 \mathrm{~mL} \text { of } \mathrm{THF}+28 \mathrm{mg} \\
\text { dried 1, leaving for } 24 \\
\mathrm{~h}\end{array}$ & $0.11 \%$ & $0.09 \%$ \\
\hline
\end{tabular}

